\title{
Gambaran Penggunaan Antibiotik pada Pasien Bedah Orthopedi di Rumah Sakit Pusat Infeksi Prof. Dr. Sulianti Saroso Januari- Juli 2019
}

\author{
Profile of Antibiotics Usage in Orthopedic Surgery Patients at Sulianti Saroso Infectious \\ Disease Hospital in January-July 2019
}

\author{
Epi Wulandani ${ }^{1}$,Nina Mariana ${ }^{2}$, Teguh Sarry Hartono ${ }^{2}, \mathbf{M}$. Taufik $\mathbf{S}^{1}$, Chandra Wijaya $^{2}$, \\ William Chandra ${ }^{2}$, Nico Perdana Hardiansyah ${ }^{2}$ \\ ${ }^{1}$ Fakultas Farmasi Universitas 17 Agustus 1945 Jakarta, Jakarta Utara, Indonesia 14350. \\ ${ }^{2}$ RSPI Prof. Dr. Sulianti Saroso, Kementrian Kesehatan Republik Indonesia.
}

*Korespodensi Penulis :

Epi Wulandani

wulanepi@gmail.com

\begin{abstract}
Abstrak
Latar Belakang: Kejadian infeksi pada kasus bedah orthopedidapat mempengaruhi morbiditas dan mortalitas. Ketepatan penggunaan antibiotik baik profilaksis maupun empirik pada tindakan pembedahan sangat penting untuk mengurangi risiko resistensi bakteri dan Healthcare Associated Infections (HAls) contohnya Infeksi Luka Operasi (ILO). Penelitian ini bertujuan untuk mengetahui gambaran penggunaan antibiotik sebagai profilaksis dan empirik pada pasien bedah orthopedi. Metode: Penelitian observational deskriptif dengan desain cross sectional terhadap data rekam medis pasien bedah orthopedi RSPI Prof.Dr. Sulianti Saroso periode Januari-Juli 2019 yang diambil dengan teknik total sampling dengan pendekatan retrospektif. Hasil: Diperoleh 52 rekam medis yang memenuhi kriteria inklusi dengan 84 peresepan antibiotik. Pasien perempuan sebanyak $55,77 \%$ sedangkan laki-laki $44,23 \%$; jenis operasi bersih $71 \%$, kotor $17 \%$ dan bersih-terkontaminasi $12 \%$; pasien tanpa penyakit penyerta sebanyak $55,77 \%$, satu penyakit penyerta $32,70 \%$ dan $\geq 2$ penyakit penyerta $11,53 \%$. Penggunaan antibiotik terapi empirik $72,62 \%$ dan profilaksis $27,38 \%$. Antibiotik empirik dan profilaksis yang paling banyak digunakan adalah ampicillin sulbactam (42,65\% dan 52,17\%). Jenis kasus ortopedi terbanyak adalah kasus infeksi sebanyak $53 \%$. Kesimpulan: Penggunaan antibiotik empirik maupun profilksis bedah terbanyak pada pasien bedah orthopedi di RSPI Prof. Dr. Sulianti Saroso adalah ampicillin/sulbactam.
\end{abstract}

Kata kunci: antibiotik empirik; antibiotik profilaksis; bedah orthopedi

\begin{abstract}
Background: Incidence of infection in orthopedic surgery cases can affect morbidity and mortality. Appropriate use of antibiotics both prophylactic and empirical in surgery are very important to reduce the risk of bacterial resistance and Healthcare Associated Infections (HAls) for example Surgical Wound Infections (ILO). This study aims to describe the use of antibiotics including the use of antibiotics as prophylactic and empirical in orthopedic surgery patients. Methods: Descriptive research with cross sectional design on medical records of patients with orthopedic surgery at Sulianti Saroso Infectious Disease Hospital for the period January-July 2019 which was taken using a total sampling technique with a retrospective approach. Results: There were 52 medical records that met the inclusion criteria with 84 antibiotic prescriptions. Female patients were $55.77 \%$ while male patients were $44.23 \%$; type of operation net $71 \%$, gross $17 \%$ and clean-contaminated $12 \%$; patients without comorbidities were $55.77 \%$, one comorbidity was $32.70 \%$ and 2 co-morbidities were $11.53 \%$. The use of antibiotics for empirical therapy was $72.62 \%$ and prophylaxis was $27.38 \%$. The most common types of orthopedic cases were infection cases as much as 53\%. Conclusion: Results of the study revealed that the most frequently prescribed prophylaxis and empirical antibiotic for orthopedic surgery in RSPI Prof. Dr. Sulianti Saroso hospital were ampicillin/sulbactam.
\end{abstract}

Keywords : empirical antibiotics, prophylaxis antibiotic; orthopedic surgery 


\section{Pendahuluan}

Tindakan pembedahan merupakan salah satu komponen dasar dari sistem perawatan kesehatan yang sangat penting dan memiliki peran dalam mengurangi penderitaan pasien akan penyakitnya. Pembedahan dapat bersifat preventif, perawatan untuk penyakit darurat, akut dan pengobatan penyakit kronis. ${ }^{1}$ Proses pembedahan memungkinkan mikroba masuk kedalam tubuh sehingga dapat menyebabkan atau saat ini lebih dikenal sebagai Health-care Associated Infections (HAls) yang paling sering terjadi yaitu infeksi daerah operasi, infeksi saluran kemih dan Infeksi saluran pernapasan bagian bawah. $^{2}$

Pasien rawat inap di rumah sakit sering menerima antibiotik untuk mengobati dugaan maupun adanya infeksi yang sudah terkonfirmasi, yang mungkin berhubungan atau tidak dengan pembedahan. Pada pemberian antibiotik tersebut, tidak jelas apakah penambahan dosis antibiotik yang lebih dekat dengan waktu insisi diperlukan untuk mencegah Infeksi Luka Operasi (ILO). ${ }^{3}$ Centers for Disease Control and Prevention (CDC) pada tahun 2002 memperkirakan angka kejadian HealthCare Associated Infections (HAls) yaitu 1,7 juta orang dan sekitar 99.000 orang meninggal karena infeksi ini. ${ }^{4}$ Angka
HAls di Indonesia terus meningkat, hasil survei rumah sakit di DKI Jakarta yang dilakukan oleh Perhimpunan Pengendalian Infeksi Indonesia dan Rumah Sakit Penyakit Infeksi Prof. Dr. Suliati Saroso Jakarta pada tahun 2003 mendapatkan angka infeksi nosokomial untuk ILO adalah $18,9 \% .^{5}$

Untuk menghindari terjadinya infeksi daerah operasi, maka digunakan antibiotik profilaksis sebelum prosedur operasi. Antibiotika profilaksis bedah merupakan antibiotika yang diberikan sebelum adanya kontaminasi pada jaringan atau tubuh. Pada umumnya, antibiotika profilaksis dianjurkan hanya untuk tindakan dengan kejadian infeksi yang tinggi seperti pada jenis operasi bersih-terkontaminasi, operasi terkontaminasi dan tindakan dengan konsekuensi infeksi serius. ${ }^{6}$ Praktik standar untuk pencegahan infeksi luka operasi (ILO) termasuk pemberian antibiotik profilaksis dalam satu jam sebelum insisi. $^{7}$

Intensitas penggunaan antibiotik yang relatif tinggi menimbulkan berbagai permasalahan dan merupakan ancaman global bagi kesehatan terutama resistensi bakteri terhadap antibiotik. Selain berdampak pada morbiditas dan mortalitas, juga memberi dampak negatif terhadap ekonomi dan sosial yang sangat tinggi. ${ }^{8}$ Kuman resisten antibiotik tersebut terjadi akibat 
penggunaan antibiotik yang tidak bijak dan penerapan kewaspadaan standar (standard precaution) yang tidak sesuai di fasilitas pelayanan kesehatan. ${ }^{5}$ Menurut Jim O'Neil jika resistensi antibiotik tidak dikendalikan dengan baik maka diperkirakan pada tahun 2050 akan menjadi penyebab kematian utama diatas kanker, diabetes dan penyakit lainnya mencapai 10 juta kematian per tahun. ${ }^{9}$ Untuk mengurangi terjadinya ketidakrasionalan penggunaan antibiotik yang dapat mengakibatkan resistensi bakteri dan infeksi daerah operasi maka sangat diperlukan suatu tindakan evaluasi penggunaan antibiotik. ${ }^{10}$

RSPI Prof. Dr. Sulianti Saroso sebagai pusat infeksi nasional memiliki data terkait gambaran penggunaan antibiotik pada pasien bedah. Berdasarkan latar belakang tersebut diatas, penelitian dilakukan di RSPI Prof. Dr. Sulianti Saroso bertujuan untuk mengetahui gambaran penggunaan antibiotik termasuk penggunaan antibiotik sebagai profilaksis dan empirik pada pasien bedah orthopedi.

\section{Metode}

Penelitian ini merupakan penelitian observational deskriptif dengan desain potong lintang dan metode pendekatan retrospektif. Subjek penelitian menggunakan status rekam medis pasien bedah orthopedi selama periode bulan Januari-Juli 2019 dengan metode total sampling. Sampel yang memenuhi kriteria inklusi yaitu pasien yang mendapatkan tindakan bedah orthopedi dan diberikan antibiotik, catatan rekam medis yang lengkap dengan daftar pemberian terapi antibiotik dan lembar laporan operasi yaitu sebanyak 52 sampel.

Definisi operasi bersih adalah operasi yang dilakukan pada daerah kondisi prabedah tanpa infeksi, tanpa membuka traktus (respiratorius, gastrointestinal, urinarius, bilier), operasi terencana, atau penutupan kulit primer dengan atau tanpa digunakan drain tertutup. Definisi operasi bersih terkontaminasi adalah operasi dilakukan pada traktus (digestivus, bilier, uinarius, respiratorius, reproduksi kecuali ovarium) atau operasi tanpa disertai kontaminasi yang nyata. Operasi kotor adalah operasi pada perforasi saluran cerna, saluran urogenital atau saluran napas yang terinfeksi ataupun operasi melibatkan daerah purulen, dapat pula operasi pada luka terbuka lebih dari 4 jam setelah kejadian dan terdapat jaringan non vital luas atau kotor. ${ }^{5}$

Data dimasukkan ke dalam formulir yang memuat data identitas pasien, lama rawat, diagnosis, antibiotik yang digunakan (dosis, rute, interval, frekuensi, dan lama pemberian), dan 
lembar surveilans antibiotik profilaksis. Analisa hasil penelitian menggunakan analisa univariat.

\section{Hasil}

Pasien bedah orthopedi diperoleh sampel yang memenuhi kriteria inklusi sebanyak 52 kasus bedah orthopedi, termasuk didalamnya 84 pemberian antibiotik baik profilaksis maupun terapi empiris. Sampel penelitian berdasarkan data demografi (tabel 1) terdiri dari pasien perempuan 29 (55,77\%) dan laki-laki 23 (44,23\%). Distribusi usia 1216 tahun yaitu $3(5,77 \%)$, usia 17-25 tahun 4 (7,69\%), usia 26-35 tahun 5 (9,62\%), 36-45 tahun 5 (9,62\%), 46-55 tahun 7 (13,46\%), 56-65 tahun 14 (26,92\%) dan > 65 tahun 14 (26,92\%). Pasien yang menjalani tindakan bedah orthopedi dengan jenis operasi terbanyak adalah operasi bersih $71 \%$, diikuti jenis operasi kotor $17 \%$ dan operasi bersih-terkontaminasi 12\% (Tabel 1).

Profil penggunaan antibiotik pada pasien bedah orthopedi (Tabel 2) dari 52 status rekam medis terdapat 84 peresepan antibiotik yang terdokumentasi dalam lembar pemberian terapi. Selama perawatan di rumah sakit sebanyak $48 \%$ pasien mendapatkan terapi antibiotik tunggal, $42 \%$ pasien mendapatkan kombinasi dua jenis antibiotik dan $10 \%$ pasien mendapatkan kombinasi tiga jenis antibiotik. Rute pemberian antibiotik per oral $6 \%$ diberikan pada pasien stabil dan dapat minum secara oral. Pemberian antibiotik rute intravena sebanyak $94 \%$. Tujuan penggunaan antibiotik sebagai profilaksis bedah $27 \%$ dan antibiotik terapi empiris $73 \%$. Kasus penyakit terbanyak adalah kasus infeksi (53\%). Berdasarkan Tabel 3, diketahui bahwa penggunaan antibiotik empirik maupun profilksis bedah terbanyak pada pasien bedah orthopedi adalah ampicillin/ sulbactam.

Tabel 1. Karakteristik Pasien Bedah Orthopedi $(n=52)$

\begin{tabular}{|c|c|c|}
\hline Variabel & $\mathbf{n}$ & $\%$ \\
\hline \multicolumn{3}{|l|}{ Usia } \\
\hline - $12-16$ & 3 & 5,77 \\
\hline - $17-25$ & 4 & 7,69 \\
\hline - $\quad 26-35$ & 5 & 9,62 \\
\hline - $\quad 36-45$ & 5 & 9,62 \\
\hline - $46-55$ & 7 & 13,46 \\
\hline - $\quad 56-65$ & 14 & 26,92 \\
\hline - $>65$ & 14 & 26,92 \\
\hline \multicolumn{3}{|l|}{ Jenis Kelamin } \\
\hline - Laki-laki & 23 & 44,23 \\
\hline - Perempuan & 29 & 55,77 \\
\hline \multicolumn{3}{|l|}{ Jenis Operasi } \\
\hline - Bersih & 37 & 71 \\
\hline - Kotor & 9 & 17 \\
\hline $\begin{array}{l}\text { - Bersih- } \\
\text { terkontaminasi }\end{array}$ & 6 & 12 \\
\hline \multicolumn{3}{|l|}{ Penyakit Penyerta } \\
\hline - Tidak Ada & 29 & 55,77 \\
\hline - Satu jenis & 17 & 32,70 \\
\hline $\begin{array}{l}\text { - Dua jenis atau } \\
\text { lebih }\end{array}$ & 6 & 11,53 \\
\hline
\end{tabular}


Tabel 2. Profil Penggunaan Antibiotik

\begin{tabular}{lcc}
\hline Variabel & Frekuensi & Persentase (\%) \\
\hline Penggunaan antibiotik & $\mathbf{( n = 5 2 )}$ & \\
Tunggal & 25 & 48 \\
Dua Jenis & 22 & 42 \\
Tiga Jenis & 5 & 10 \\
\hline Rute Pemberian & $(\mathbf{n = 8 4 )}$ & \\
Per Oral & 5 & 6 \\
Intravena & 79 & 94 \\
\hline Jenis Terapi & $\mathbf{( n = 8 4 )}$ & \\
Profilaksis & 23 & 27 \\
Empiris & 61 & 73 \\
\hline Jenis Kasus Orthopedi & $(\mathbf{n = 6 2 )}$ & \\
Infeksi & 33 & 53 \\
Non Infeksi & 29 & 47 \\
\hline
\end{tabular}

Tabel 3. Penggunaan Antibiotik Berdasarkan Tipe Terapi

\begin{tabular}{lcc}
\hline \multirow{2}{*}{ Jenis Antibiotik } & \multicolumn{2}{c}{ Terapi } \\
\cline { 2 - 3 } & ADE (\%) & ADP (\%) \\
\hline Ampicillin Sulbactam & $26(42,65)$ & $12(52,17 \%)$ \\
Cefazolin & $1(1,63 \%)$ & $2(8,69 \%)$ \\
Cefixime & $3(4,91 \%)$ & $0(0)$ \\
Cefoperazone & $7(11,47 \%)$ & $5(21,74 \%)$ \\
Cefotaxime & $4(6,55 \%)$ & $1(4,34 \%)$ \\
Ceftriaxon & $2(3,27 \%)$ & $0(0)$ \\
Metronidazol & $8(13,12 \%)$ & $1(4,34 \%)$ \\
Gentamycin & $4(6,55 \%)$ & $0(0)$ \\
Azithromycin & $1(1,63 \%)$ & $0(0)$ \\
Vancomycin & $5(8,19 \%)$ & $0(0)$ \\
\hline Total peresepan $\mathbf{( n = 8 4 )}$ & $\mathbf{6 1 ( 7 2 , 6 2 \% )}$ & $\mathbf{2 3}(\mathbf{2 7 , 3 8 \% )}$
\end{tabular}

Keterangan : ADE : Antimicrobial Drugs Empiric ; ADP : Antimicrobial Drugs Prophylaxis

\section{Pembahasan}

Berdasarkan data penelitian ini, pasien didominasi perempuan berusia diatas 50 tahun dengan diagnosis fraktur terbuka maupun tertutup akibat osteoporosis, serta penyakit tulang lainnya seperti osteoartritis, osteomielitis, selulitis dan sebagainya. Hal ini erat kaitannya dengan berkurangnya kepadatan tulang pada usia dewasa. Penelitian serupa oleh Nungki mengemukakan bahwa pasien bedah orthopedi lebih banyak yang berjenis kelamin perempuan karena umumnya pasien perempuan tidak bisa menahan rasa sakit sehingga dapat mengganggu aktifitas. ${ }^{11}$ Dari semua pasien yang menjalani tindakan bedah 
orthopedi tersebut, jenis operasi yang terbanyak adalah operasi bersih. Sebagian besar bedah orthopedi merupakan operasi bersih karena kondisi pra bedah tanpa infeksi. ${ }^{12}$

Pemberian terapi antibiotik terbagi menjadi 2 jenis, yaitu antibiotik profilaksis dan antibiotik terapi empiris. Antibiotik profilaksis sendiri dibagi menjadi dua golongan yaitu profilaksis bedah dan profilaksis non bedah. Antibiotik profilaksis yang dimaksud dalam penelitian ini tentunya adalah antibiotik profilaksis bedah yang diberikan sesaat sebelum tindakan pembedahan di mulai. Antibiotik profilaksis bedah bertujuan mencegah terjadinya infeksi luka daerah operasi dan diberikan sebelum, selama, dan paling lama 24 jam pasca bedah pada kasus bedah yang secara klinis tidak memperlihatkan tanda infeksi. ${ }^{12}$ Prinsip penggunaan antibiotika profilaksis selain tepat dalam pemilihan jenis juga mempertimbangkan konsentrasi antibiotika dalam jaringan saat mulai dan selama operasi berlangsung. ${ }^{12}$ Rekomendasi antibiotika yang digunakan pada profilaksis bedah dalam panduan Kementerian kesehatan Republik Indonesia maupun PPRA di RSPI prof. Dr. Sulianti Saroso adalah cephalosporin generasi I-II. ${ }^{5,12}$ Dosis tunggal Cefazolin (golongan cephalosporin generasi I) sebagai dosis profilaksis sebelum pembedahan merupakan rekomendasi kuat. Sebagai alternatif adalah ampicillin sulbactam dan cephalosporin generasi II. ${ }^{13,14}$

Meskipun antibiotik profilaksis mempunyai peran penting dalam mengurangi tingkat Surgical Site Infection (SSI), faktor-faktor lain contohnya perhatian pada strategi pengendalian infeksi, dasar pengalaman dan teknik, durasi prosedur, lingkungan rumah sakit dan ruang operasi, instrumen sterilisasi, persiapan pra operasi (misalnya, pembedahan scrub, antiseptik kulit, hair removal yang tepat), perioperative (suhu dan kontrol glikemik), dan kondisi medis yang mendasari pasien, dapat memungkin berdampak yang kuat pada tingkat SSI. ${ }^{13}$

Selain antibiotik profilaksis bedah, terdokumentasi juga penggunaan antibiotik terapi empiris. Penggunaan antibiotik pada terapi empiris karena belum diketahuinya mikroba penyebab infeksi serta tingkat kepekaan terhadap bakteri tersebut. Dalam pemilihan antibiotik terapi empiris, terdapat beberapa hal yang harus diperhatikan : (1) lokasi infeksi dan jenis bakteri yang memungkinkan berkoloni di lokasi tersebut, (2) data sebelumnya tentang adanya kolonisasi bakteri pada pasien, (3) pola kepekaan bakteri lokal atau antibiogram yang tersedia untuk 
patogen-patogen penting di rumah sakit. $^{15}$

Penggunaan antibiotik terbanyak baik sebagai terapi empiris maupun profilaksis bedah dari hasil penelitian ini adalah Ampicillin/Sulbactam.Kombinasi keduanya dikenal sebagai antibakteri spektrum luas yang peka terhadap bakteri gram positif maupun gram negatif yang peka terhadap Beta Lactamase. $^{5}$ Antibiotik golongan sefalosporin generasi pertama dan ketiga juga digunakan pada terapi empiris dan profilaksis pasien bedah orthopedi. Pada panduan yag tercantum tidak dianjurkan menggunakan cephalosporin generasi III-IV, golongan carbapenem, dan golongan quinolone untuk profilaksis bedah.

Indikasi penggunaan metronidazol pada terapi empiris maupun profilaksis bedah karena adanya dugaan infeksi bakteri anaerob. Metronidazol merupakan antibiotik kombinasi yang banyak digunakan pada infeksi ulkus kaki diabetik. ${ }^{16}$ Penggunaan Azithromycin terdokumenkasi pada pasien bedah orthopedi dengan penyakit bawaan pneumonia. ${ }^{17}$

\section{Kesimpulan}

Penggunaan antibiotik empirik maupun profilksis bedah terbanyak pada pasien bedah orthopedi di RSPI Prof. Dr. Sulianti Saroso sesuai dengan hasil penelitian lainnya adalah ampicillin/sulbactam.

\section{Saran}

Dilakukan evaluasi antibiotik menggunakan alur gyysen guna menilai kualitas antibiotik yang digunakan. Selain itu penggunaan antibiotik disarankan mempertimbangkan cost effectivenessnya.

\section{Ucapan Terima Kasih}

Penulis mengucapkan terima kasih kepada Direktur Utama RSPI-SS beserta jajaran direksi, Instalasi Penelitian Rumah Sakit dan seluruh staf dari devisi yang terlibat dalam pelaksanaan penelitian ini.

\section{Daftar Pustaka}

1. Rose J, Weiser TG, Hider P, Wilson L, Gruen RL, Bickler SW. Estimated need for surgery worldwide based on prevalence of diseases: A modelling strategy for the WHO Global Health Estimate. Lancet Glob Heal. 2015;

2. WHO. Prevention of hospitalacquired infections A Practical Guide 2nd edition. WHO. 2002;

3. Nguyen CT, Reuter CM, Hudson T, $\mathrm{Li} \mathrm{J}$. Evaluation of surgical site infection antibiotic prophylaxis among patients receiving antibiotics for active infection. Journal of Hospital Infection. 2019.

4. Mauger B, Marbella A, Pines E, 
Chopra R, Black ER, Aronson N. Implementing quality improvement strategies to reduce healthcareassociated infections: A systematic review. Am J Infect Control. 2014;

5. Permenkes RI. PERMENKES RI NO 2406/MENKES/PER/XII/2011

Pedoman Umum Penggunaan Antibiotik. Permenkes RI. 2011;

6. Bratzler DW, Dellinger EP, Olsen KM, Perl TM, Auwaerter PG, Bolon MK, et al. Clinical practice guidelines for antimicrobial prophylaxis in surgery. Am J Heal Pharm. 2013;

7. Anderson DJ, Podgorny K, BerríosTorres SI, Bratzler DW, Dellinger EP, Greene L, et al. Strategies to Prevent Surgical Site Infections in Acute Care Hospitals: 2014 Update. Infect Control Hosp Epidemiol. 2014;

8. Purwanti O, Abdulah R, Pradipta I, Rahayu C. Analisis Minimalisasi Biaya Penggunaan Empirik Pasien Sepsis Sumber Infeksi Pernapasan. Indones J Clin Pharm. 2014;

9. O' Neil J. Review on Antibiotic resisitance.

Antimicrobial

Resistance: Tackling a crisis for the health and wealth of nations. Health and Wealth Nations. 2014.

10. Gyssens IC. Audits for monitoring the quality of antimicrobial prescriptions. In: Antibiotic Policies: Theory and Practice. 2005.

11. Nungki A. Pola Penggunaan
Antibiotik Profilaksis Bedah Orthopedi pada Tindakan TKR dan THR di Rumah Sakit Orthopedi Prof. Dr. R. Soeharso Surakarta Tahun 2017. Surakarta: Universitas Setia Budi; 2018.

12. RSPI Prof. Dr. Sulianti Saroso. Panduan Penggunaan antimikroba. 2018.

13. ASHP Therapeutic Guidelines. Clinical Practice Guidelines for Antimicrobial Prophylaxis in Surgery [Internet]. 2021 [cited 2021 Jun 2]. Available from: https://www.ashp.org.

14. Ullman MA RJ. Antimicrobial prophylaxis in surgery. Pharmacother Princ Pract Fourth Ed. 2016;

15. Letourneau AR, Calderwood MS, Huang SS, Bratzler DW, Ma A, Yokoe DS. Harnessing Claims to Improve Detection of Surgical Site Infections following Hysterectomy and Colorectal Surgery. Infect Control Hosp Epidemiol. 2013;

16. Agistia $\mathrm{N}$, Mukhtar $\mathrm{H}$, Nasif $\mathrm{H}$. Efektifitas Antibiotik pada Pasien Ulkus Kaki Diabetik. J Sains Farm Klin. 2017;

17. American Society of Health-System Pharmacists. AHFS Drug Information Essentials. American Society of Health-System Pharmacists. 2020. 